\title{
Di(isothiocyanato)bis(4-methyl-4'-vinyl-2,2'-bipyridine) Ruthenium(II) Films Deposited on Titanium Oxide-Coated, Fluorine-Doped Tin Oxide for an Efficient Solar Cell
}

\author{
Yi Liu, Ryuichi Sugimoto, Katsuhiro Sumi* \\ School of Environmental Science and Engineering, Kochi University of Technology, Kami, Japan \\ Email: * sumi.katsuhiro@kochi-tech.ac.jp
}

Received March 15, 2013; revised April 17, 2013; accepted April 25, 2013

Copyright (C) 2013 Yi Liu et al. This is an open access article distributed under the Creative Commons Attribution License, which permits unrestricted use, distribution, and reproduction in any medium, provided the original work is properly cited.

\begin{abstract}
Dye-sensitized titanium oxide electrodes were prepared by immobilizing a novel ruthenium complex, di(isothiocyanato)bis(4-methyl-4'-vinyl-2,2'-bipyridine)ruthenium(II) [(NCS $\left.)_{2}(\operatorname{mvbpy})_{2} \mathrm{Ru}(\mathrm{II})\right]$ or the ruthenium complex/sodium 4-vinylbenzenesulfonate onto the surface of a titanium oxide-coated, fluorine-doped tin oxide $\left(\mathrm{TiO}_{2} / \mathrm{FTO}\right)$ electrode through a new electrochemically initiated film formation method, in which the electrolysis step and the film deposition step were individually performed. The incident photon-to-current conversion efficiency (IPCE) of the Ru complex film on a $\mathrm{TiO}_{2} / \mathrm{FTO}$ electrode was disappointedly insufficient $(1.2 \%$ at $440 \mathrm{~nm})$. In sharp contrast, the Ru(II) complex/sodium 4-vinylbenzenesulfonate composite film deposited on the surface of a $\mathrm{TiO}_{2} / \mathrm{FTO}$ electrode showed maximum IPCE of $31.7 \%$ at $438 \mathrm{~nm}$.
\end{abstract}

Keywords: Methylvinylbipyridine; Ruthenium Complex; Dye-Sensitized Solar Cell; Photon-to-Current Conversion Efficiency

\section{Introduction}

Dye-sensitized solar cells (DSSCs) have been attracting abundant attention as technically and economically credible alternatives to traditional silicon-based solar cells [1-5]. As a key component of DSSCs, photosensitizers that can absorb sunlight and inject an electron into the conducting band of nanocrystalline $\mathrm{TiO}_{2}$ have been mainly focused in DSSC research; photosensitizers having a general structure of $\operatorname{RuL}_{2}(\mathrm{X})_{2}$, where $\mathrm{L}$ stands for functionalized 2,2'-bipyridine such as 4,4'-dicarboxyl-2, 2'-bipyridine and $\mathrm{X}$ presents halide, cyanide, thiocyanate, thiolate, thienyl or ancillary water, have been extensively investigated over the past two decades [6-13]. Incident photon-to-current conversion efficiency (IPCE) is one of critical parameters for the evaluation of the performance of solar cells $[14,15]$. Among solar cells developed so far, that fabricated with $\mathrm{N}_{3}$ dye (cis-(dcbpy) $)_{2}(\mathrm{NCS})_{2}$ ruthenium(II): dcbpy $=4,4^{\prime}$-dicarboxyl-2,2'-bipyridine) shows IPCE of about $85 \%$ in a visible light region [16].

Dyes are commonly immobilized onto a semiconductor (typically $\mathrm{TiO}_{2}$ ) surface with a functional group, such

"Corresponding author. as carboxyl, phosphono or thio group in the dyes. Up to now, $\mathrm{Ru}$ (II) complexes without these functional groups cannot be candidates in DSSC research due to impossibility of immobilization; this drawback has limited the development of effective photosensitizers.

Herein, we report a new, electrochemically induced film formation method, which can immobilize

di(isothiocyanato)bis(4-methyl-4'-vinyl-2,2'-bipyridine) ruthenium(II), and a novel type of dye-sensitized solar cells with sufficient IPCE.

\section{Experimental Section}

\subsection{Instruments}

${ }^{1} \mathrm{H}$ NMR spectra were measured on a Bruker Ascend 400 spectrometer. Chemical shifts were determined with respect to the residual solvent peak ( $\delta$ in ppm, $J$ in $\mathrm{Hz}$ ). Matrix-assisted laser desorption/ionization time-of-flight (MALDI-TOF) mass spectra were acquired on a Bruker autoflex speed-KE in a reflection mode with $\alpha$-cyano4-hydroxycinnamic acid (CCA) as a matrix. FT-IR spectra were recorded on a JASCO FT/IR-610 spectrometer as $\mathrm{KBr}$ pellets. Ultraviolet-visible absorption (UV-vis) 
spectra were measured on a Perkin Elmer Lambda 19 $\mathrm{UV} /$ vis/NIR spectrometer. Cyclic voltammograms were recorded on a $\mathrm{CH}$ instrument 701 electrochemical analyzer at a sweep rate of $100 \mathrm{mV} \cdot \mathrm{s}^{-1}$ by using $0.1 \mathrm{M}$ tetrabutylammonium perchlorate (TBAP) as an electrolyte solution, $\mathrm{Pt}$ wire as a counter electrode, and $\mathrm{Ag}$ / $\mathrm{AgCl}$ as a reference electrode.

\subsection{Materials}

All reactions were performed under argon atmosphere. All reagents were purchased from Wako Pure Chemical Industries Ltd except for $\mathrm{NH}_{4} \mathrm{SCN}$ and sodium 4-vinylbenzenesulfonate, which were purchased from Nacac Tesque, Inc. The reagents were used as received, except for 4,4'-dimethylbipyridine which was recrystallized from methanol prior to use. Dry tetrahydrofuran (THF) was distilled over $\mathrm{Na}$ and benzophenone. 2-(4'-Methyl(2,2'-bipyridin-4-yl)ethanol [17,18] and 4-methyl-4'vinyl-2,2'-bipyridine [19] were synthesized according to the procedures in the literatures with some modifications. Di(isothiocyanato)-bis(4-methyl-4'-vinyl-2,2'-bipyridine)ruthenium(II) was prepared by a method similar to that of bis(2,2'-bipyridine)diisothiocyanatoruthenium(II) [20].

\subsubsection{2-(4'-Methyl-2,2'-bipyridin-4-yl)ethanol}

4,4'-Dimethyl-2,2'-bipyridine (6.8 g, $36.91 \mathrm{mmol})$ was dissolved in dry THF $(400 \mathrm{~mL})$, and the solution was cooled down to $0^{\circ} \mathrm{C}$ by ice/water. Lithium diisopropylamide $(20.3 \mathrm{~mL}, 2 \mathrm{M}$ in THF, $40.60 \mathrm{mmol})$ was added dropwise to the solution. The purple solution was stirred at $0^{\circ} \mathrm{C}$ for $2 \mathrm{~h}$, and then a large excess amount of dry paraformaldehyde (5.5 g, $183 \mathrm{mmol}$ as formaldehyde) was added all at once to the solution. The mixture was allowed to warm to room temperature and stir for $24 \mathrm{~h}$. The color of the solution gradually turned from purple to light yellow. The reaction was quenched with distilled water $(200 \mathrm{~mL})$, and the solution was concentrated to about $50 \mathrm{~mL}$ under reduced pressure. The residue was extracted with dichloromethane $(3 \times 50 \mathrm{~mL})$, and the extracts were concentrated under reduced pressure. The yellow viscous liquid remained was purified on neutral alumina gel column chromatography; after washing off unreacted 4,4'-dimethyl-2,2'-bipyridine with hexane/ethyl acetate $(19: 1, \mathrm{v} / \mathrm{v})$, the yellow-colored fraction eluted with hexane/ethyl acetate $(2: 1, \mathrm{v} / \mathrm{v})$ was collected. The fraction was condensed under reduced pressure to afford light-yellow oil (2.27 g, 29\%). ${ }^{1} \mathrm{H}$ NMR (400 MHz, $\left.\mathrm{CDCl}_{3}\right) \delta(\mathrm{ppm}): 8.56(\mathrm{~d}, 1 \mathrm{H}, J=5.0 \mathrm{~Hz}, \mathrm{PyH}), 8.50(\mathrm{~d}$, $1 \mathrm{H}, J=5.0 \mathrm{~Hz}, \mathrm{PyH}), 8.25$ (s, 1H, PyH), 8.20 (s, 1H, PyH), 7.18 (dd, 1H, $J_{1}=5.0 \mathrm{~Hz}, J_{2}=1.6 \mathrm{~Hz}, \mathrm{PyH}$ ), 7.13 $(\mathrm{d}, 1 \mathrm{H}, J=4.9 \mathrm{~Hz}, \mathrm{PyH}), 3.96(\mathrm{t}, 2 \mathrm{H}, J=6.5 \mathrm{~Hz}$, $\mathrm{CH}_{2} \mathrm{CH}_{2} \mathrm{OH}$ ), 2.95 (t, $2 \mathrm{H}, J=6.4 \mathrm{~Hz}, \mathrm{CH}_{2} \mathrm{CH}_{2} \mathrm{OH}$ ), 2.44 (s, $3 \mathrm{H}, \mathrm{CH}_{3}$ ).

\subsubsection{4-Methyl-4'-vinyl-2,2'-bipyridine (mvbpy)}

2-(4'-Methyl-2,2'-bipyridin-4-yl)ethanol (2.27 g, 10.7 mmol), 4-t-butylpyrocatechol $(0.1 \mathrm{~g}, 0.6 \mathrm{mmol})$ and finely powdered sodium hydroxide $(4.28 \mathrm{~g}, 107 \mathrm{mmol})$ were successively added to benzene $(5 \mathrm{~mL})$. The blue mixture was then heated at $115^{\circ} \mathrm{C}$ for $2 \mathrm{~h}$ under reduced pressure $(<1 \mathrm{mmHg})$. The crude product was purified on silica gel column chromatography by using dichloromethane/methanol $(100: 1, \mathrm{v} / \mathrm{v})$ as an eluent. The corresponding fractions were concentrated under reduced pressure to yield a colorless solid (1.0 g, 48\%). ${ }^{1} \mathrm{H}$ NMR $\left(400 \mathrm{MHz}, \mathrm{CDCl}_{3}\right) \delta(\mathrm{ppm}): 8.62(\mathrm{~d}, 1 \mathrm{H}, J=5.0 \mathrm{~Hz}$, PyH), 8.55 (d, 1H, $J=5.0 \mathrm{~Hz}, \mathrm{PyH}), 8.40$ (s, 1H, РyH), $8.24(\mathrm{~s}, 1 \mathrm{H}, \mathrm{PyH}), 7.30\left(\mathrm{dd}, 1 \mathrm{H}, J_{1}=5.1 \mathrm{~Hz}, J_{2}=1.8 \mathrm{~Hz}\right.$, PyH), 7.14 (d, 1H, $J=4.9 \mathrm{~Hz}, \mathrm{PyH}), 6.77$ (dd, 1H, $J_{1}=$ $\left.14.32 \mathrm{~Hz}, J_{2}=6.8 \mathrm{~Hz}, \mathrm{PyH}\right), 6.09(\mathrm{~d}, 1 \mathrm{H}, J=17.7 \mathrm{~Hz}$, $\left.\mathrm{CH}=\mathrm{CH}_{2}\right), 5.53\left(\mathrm{~d}, 1 \mathrm{H}, J=10.9 \mathrm{~Hz}, \mathrm{CH}=\mathrm{CH}_{2}\right), 2.44$ (s, $\left.3 \mathrm{H}, \mathrm{CH}_{3}\right)$.

\subsubsection{Di(isothiocyanato)bis(4-methyl-4'-vinyl-2, 2'-bipyridine) Ruthenium(II) $\left[(\mathrm{NCS})_{2}(\mathrm{mvbpy})_{2} \mathbf{R u}(\mathrm{II})\right]$}

4-Methyl-4'-vinyl-2,2'-bipyridine (0.400 g, $2.04 \mathrm{mmol})$ was added to a solution of $\mathrm{RuCl}_{3}(0.211 \mathrm{~g}, 1.01 \mathrm{mmol})$ in DMF $(20 \mathrm{~mL})$. After the mixture was refluxed for $8 \mathrm{~h}$ in the dark, $\mathrm{NH}_{4} \mathrm{NCS}(6.367 \mathrm{~g}, 8.36 \mathrm{mmol})$ was added all at once at room temperature. The solution was refluxed again for $12 \mathrm{~h}$ and cooled down to room temperature. Upon adding methanol $(200 \mathrm{~mL})$ to the reaction mixture, a purple red powder was deposited, which was collected by filtration over a G4 glass filter. The purple powder was thoroughly washed with cold methanol $(20 \mathrm{~mL})$ and diethyl ether $(15 \mathrm{~mL})$, and dried for $12 \mathrm{~h}$ under reduced pressure to give $(\mathrm{NCS})_{2}(\mathrm{mvbpy})_{2} \mathrm{Ru}(\mathrm{II})(0.24 \mathrm{~g}, 38 \%)$. $v_{\max }\left(\mathrm{KBr}, \mathrm{cm}^{-1}\right): 2104(\mathrm{CN}, \mathrm{s}), 1400\left(\mathrm{CH}_{3}, \mathrm{~s}\right)$. MALDITOF MS: calculated for $\mathrm{C}_{28} \mathrm{H}_{24} \mathrm{~N}_{6} \mathrm{~S}_{2} \mathrm{Ru}$ : $[\mathrm{M}]^{+}=610.0548$; found 610.0517 with isotope peaks in agreement with those obtained by a calculation.

\subsection{Immobilization}

The immobilization was performed in three steps under argon atmosphere. All solvents used were purged with argon for $15 \mathrm{~min}$.

Step 1: The electrochemical treatment of an electrode was performed in a one-compartment cell according to the three-electrode method $\left(\mathrm{TiO}_{2}\right.$-coated, fluorine-doped tin oxide $\left(\mathrm{TiO}_{2} / \mathrm{FTO}\right)$ as a working electrode, $\mathrm{Pt}$ wire as a counter electrode, and $\mathrm{Ag} / \mathrm{AgCl}$ as a reference electrode) by using a $\mathrm{CH}$ instrument 701 electrochemical analyzer. These electrodes were dipped in an electrolytic solution containing $0.1 \mathrm{M}$ of TBAP, and swept between $0-n-0 \mathrm{~V}$ $(\mathrm{n}=2,4,6,8$, and 10$)$ at a rate of $100 \mathrm{mV} \cdot \mathrm{s}^{-1}$ with bubbling with argon during the electrolysis. 
Step 2: After the electrolysis, the working electrode was soaked in a washing solvent for several seconds to remove adsorbents on the $\mathrm{TiO}_{2} /$ FTO surface.

Step 3: The electrode was dipped into a solution of $(\mathrm{NCS})_{2}(\mathrm{mvbpy})_{2} \mathrm{Ru}$ (II) $(1 \mathrm{mM})$ or the $\mathrm{Ru}$ complex/sodium 4-vinylbenzenesulfonate $(1 \mathrm{mM}$ and $1 \mathrm{mM}$, respectively) in DMF (30 mL), and kept for appropriate hours in the dark under argon atmosphere. Then, the electrode was taken out, washed with acetone $(30 \mathrm{~mL})$, and dried at room temperature in air to give the $\mathrm{Ru}$ complex film.

\subsection{Measurement of Incident Photon-to-Current Conversion Efficiency (IPCE) of the Ru(II) Complex Films}

A fluorometer (Horiba Jobin Yvon-Spex fluorolog, Horiba Inc.) equipped with a xenon lamp (Fluorolog instruments S.A., Inc.) was used in order to generate monochromatic lights from $350 \mathrm{~nm}$ to $750 \mathrm{~nm}$ with a width of $5 \mathrm{~nm}$. The photon number was counted by an optometer (Photometer S370 UDT, Gamma Scientific Inc.). The electrical quantities were measured with an electrometer (Keithley 6514 system electrometer, Keithley Instruments Inc.). The DSSC was fabricated from $\mathrm{TiO}_{2} /$ FTO coated with the $\mathrm{Ru}(\mathrm{II})$ complex film (photoanode), FTO (photocathode), and LiI/ $\mathrm{I}_{2}\left(0.5 \mathrm{M} / 1.1 \times 10^{-3}\right.$ $\mathrm{M})$ in $\mathrm{CH}_{3} \mathrm{CN}$ (mediator).

\section{Results and Discussion}

\subsection{Formation of Di(isothiocyanato) bis(4-methyl-4'-vinyl-2,2'-bipyridine) Ruthenium(II) film on the Surface of a Titanium Oxide-Coated, Fluorine-Doped Tin Oxide Electrode}

Because the present Ru(II) complex, di(isothiocyanato) bis(4-methyl-4'-vinyl-2,2'-bipyridine)ruthenium(II) $\left[(\mathrm{NCS})_{2}(\mathrm{mvbpy})_{2} \mathrm{Ru}(\mathrm{II})\right]$, has no functional group reactive with $\mathrm{TiO}_{2}$ such as carboxyl, phosphono or thio group, this complex cannot be immobilized onto the surface of $\mathrm{TiO}_{2}$-coated, fluorine-doped tin oxide $\left(\mathrm{TiO}_{2} /\right.$ FTO) electrode with conventional film formation methods that have been adopted in the fabrication of DSSCs. Paying our attention to the fact that the $\mathrm{Ru}$ complex has vinyl groups, we at first tried to immobilize the $\mathrm{Ru}$ complex onto a $\mathrm{TiO}_{2} / \mathrm{FTO}$ surface by the electrolysis of a solution of the Ru complex. However, the attempt resulted in failure, most likely due to the decomposition of the Ru complex during the electrolysis. After numerous trials, we finally found a stepwise, electro-chemically induced film formation method to give a film-like deposit of the $\mathrm{Ru}$ complex on the surface of $\mathrm{TiO}_{2} /$ FTO. This method is composed of three steps: Step 1, the electrolysis of a $\mathrm{TiO}_{2} / \mathrm{FTO}$ electrode only; Step 2, the washing of the electrode with a sol- vent; Step 3, the immobilization of the Ru complex upon immersing the washed electrode in a solution of the Ru complex. Figure 1 schematically represents the immo- bilization procedure.

The immobilization was found to be very sensitive to the history of the potential scanned onto a $\mathrm{TiO}_{2} / \mathrm{FTO}$ electrode (Step 1). Figures 2 and $\mathbf{3}$ show the cyclic voltammograms during the electrolysis of the electrodes in ranges of $0-n-0 \mathrm{~V}(\mathrm{n}=2,4,6,8$, and 10) at a rate of $100 \mathrm{mV} \cdot \mathrm{s}^{-1}$ and the UV-vis spectra of the resultant electrodes. As shown in Figure 2, an irregular trace in the cyclic voltammograms was observed in a range of $1-3.5 \mathrm{~V}$ independent on the potential applied, which would correspond to irreversible oxidation.

Moreover, it is clear from Figure 3 that the electrochemically initiated film deposition of the Ru complex took place only when the electrode, potentially swept between $0-8-0 \mathrm{~V}$ at a rate of $100 \mathrm{mV} \cdot \mathrm{s}^{-1}$, was used. As shown in Figure 4, the electrode was colored after Step 3 , undoubtedly indicating the film deposition. Moreover, the film deposited was insoluble in any sol- vents including aprotic polar solvents such as DMF and DMSO. These changes strongly support the deposition of the Ru complex through some reaction.

The electrochemically initiated film deposition method was also affected by solvents used in Steps 1-3. As shown in Figure 5, the solvent used in Step 1 influenced, to considerable extent, the quantity of the $\mathrm{Ru}$

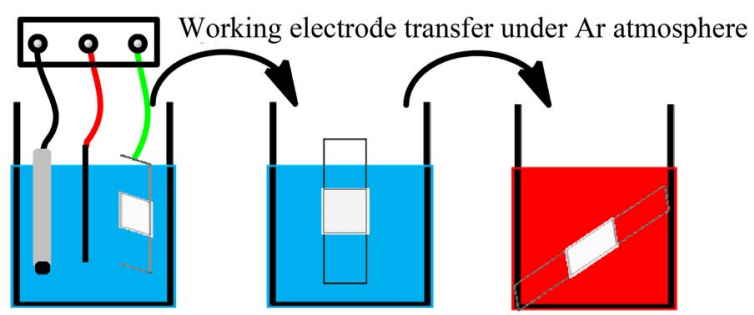

Figure 1. Schematic representation of the immobilization procedure.

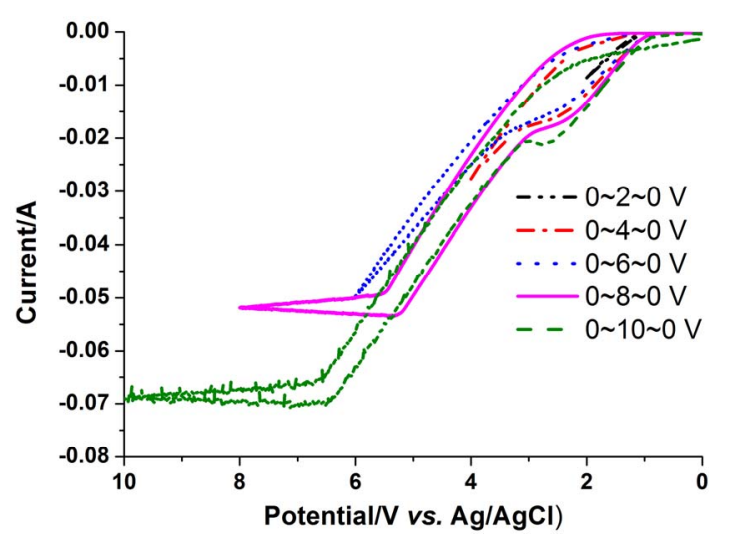

Figure 2. Cyclic voltammograms of $\mathrm{TiO}_{2} / \mathrm{FTO}$ electrodes at a scan rate of $100 \mathrm{mV} \cdot \mathrm{s}^{-1}$ in Step 1. 


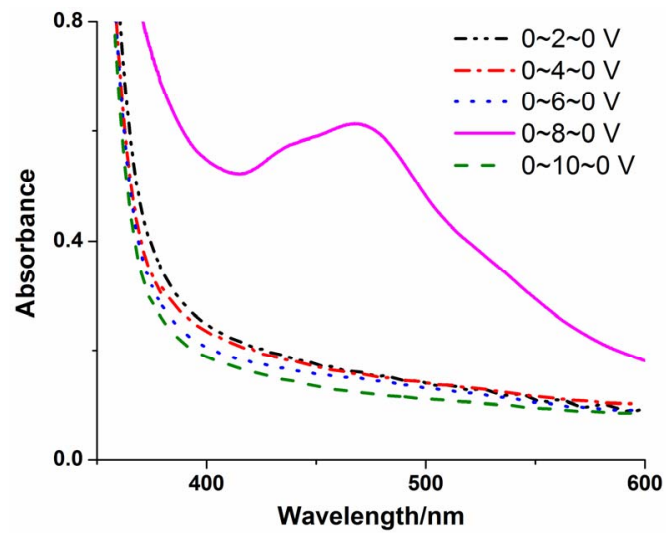

Figure 3. Uv-vis spectra of the resultant $\mathrm{TiO}_{2} / \mathrm{FTO}$ electrodes.

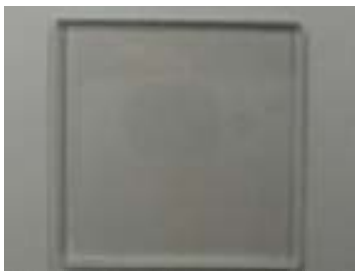

Before film deposition

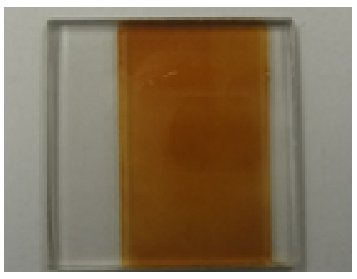

After film deposition
Figure 4. Electrodes before and after film deposition. (The electrodes were potentially swept between 0-8-0 $\mathrm{V}$ at a rate of $100 \mathrm{mV} \cdot \mathrm{s}^{-1}$ in Step 1).

complex which finally immobilized on the surface of a $\mathrm{TiO}_{2} /$ FTO electrode; although dichloromethane gave a better result than acetonitrile or methanol did, it was very hard to maintain steady conditions for the electrolysis due to the evaporation of dichloromethane upon bubbling argon during the electrolysis. Then, acetonitrile, which was better than methanol, was used in Step 1. In Step 2, no film was formed on the surface of $\mathrm{TiO}_{2} / \mathrm{FTO}$, when the electrode was washed with DMF instead of acetonitrile. Because the Ru complex is soluble only in DMF and DMSO among common organic solvents, the immobilization, Step 3, was carried out by using DMF or DMSO. To our surprise, the film was just formed on a $\mathrm{TiO}_{2} / \mathrm{FTO}$ surface, only when DMF was used as the solvent.

Figure 6 shows the effect of the dipping time in Step 3 on the electrochemically initiated film deposition. The absorption arising from the $\mathrm{Ru}$ complex on the surface of $\mathrm{TiO}_{2} /$ FTO increased continuously with prolonging the dipping time. In sharp contrast, when a $\mathrm{TiO}_{2} /$ FTO electrode without any electrochemical treatment was directly dipped into a DMF solution of the $\mathrm{Ru}$ complex for $24 \mathrm{~h}$, no absorption of the $\mathrm{Ru}$ complex was observed, indicating that the film was not formed at all on the $\mathrm{TiO}_{2} /$ FTO surface without electrochemical treatment.
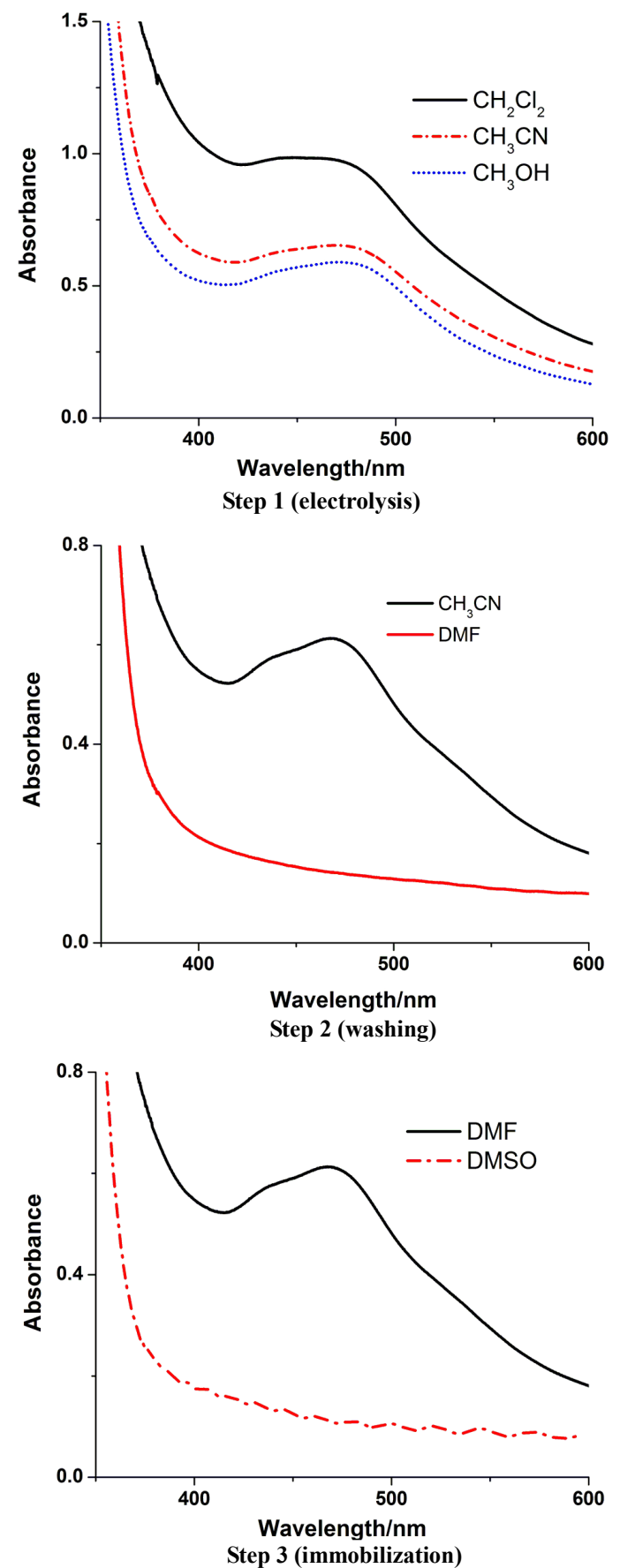

Figure 5. Effect of solvents on the formation of the Ru complex deposit.

\subsection{Active Species Generated on the Surface of $\mathrm{TiO}_{2} /$ FTO by the Electrochemical Treatment}

In order to know the active species generated on the $\mathrm{TiO}_{2} /$ FTO surface by the electrochemical treatment (Step 1), 2,2,6,6-tetramethylpiperidine-1-oxyl (TEMPO), a typical radical capture, was added to the washing solvent in Step 2 (acetonitrile); after the electrolysis in Step 1, the electrode was transferred into acetonitrile containing 
TEMPO (50 mM) for $2 \mathrm{~h}$ in Step 2. Then, the electrode was immersed into a DMF solution of Ru complex for 24 h (Step 3). As shown in Figure 7, the deposition of the $\mathrm{Ru}$ complex was considerably inhibited by TEMPO. On the basis of this result, we supposed the formation of a radical species, which may react with the vinyl group in the $\mathrm{Ru}$ complex. The radical formation would be consistent with the fact that irreversible oxidation took place during the electrolysis of a $\mathrm{TiO}_{2} / \mathrm{FTO}$ electrode. The real character of the active species on the $\mathrm{TiO}_{2} / \mathrm{FTO}$ surface and the reaction mechanism for the deposition of the $\mathrm{Ru}$ complex are not clear at present; we will report elsewhere.

\subsection{Incident Photon-to-Current Conversion Efficiency of the Ru Complex Film}

Incident photon-to-current conversion efficiency (IPCE), which defines light to electricity conversion efficiency at a certain wavelength $(\lambda)$, is one of important parameters for the evaluation of a dye-sensitized solar cell (DSSC) performance. The maximum IPCE of the Ru complex film, obtained by the present method, was disappointedly only $1.2 \%$ at $440 \mathrm{~nm}$, under the standard AM $1.5 \mathrm{G}$ irradiation conditions. The low efficiency would arise from a fast back electron transfer. In general, electron transport through films takes place in association with a successive electron transfer between neighboring redox centers [21]. After an electron transfer from an excited dye to a neighboring ground-state dye, two kinds of charged moieties, positively and negatively charged moieties, were formed. Strong electrostatic interaction between the two charged dyes can accelerate electron recombination and decrease the IPCE.

\subsection{Improvement of Incident Photon-to-Current Conversion Efficiency by Using the Ru Complex/Sodium 4-vinylbenzensesulfonate Composite}

Then, we conversely considered that IPCE would be improved when the electron recombination between the layers is blocked. On the basis of the consideration, we coexisted sodium 4-vinylbenzenesulfonate with the $\mathrm{Ru}$ complex in the immobilization (Step 3) with an expectation that the sodium cations and the sulfonate groups would partially stabilize electron-accepting dye moieties and electron-donating dye moieties, respectively. Composite films consisting of the $\mathrm{Ru}$ complex and sodium 4-vinylbenzenesulfonate were similarly deposited by using a DMF solution containing the Ru complex and sodium 4-vinylbenzenesulfonate (1:1 molar ratio) in the immobilization (Step 3). Although the UV-vis absorption of the composite film decreased with the addition of sodium 4-vinylbenzenesulfonate, the IPCE of the compos-

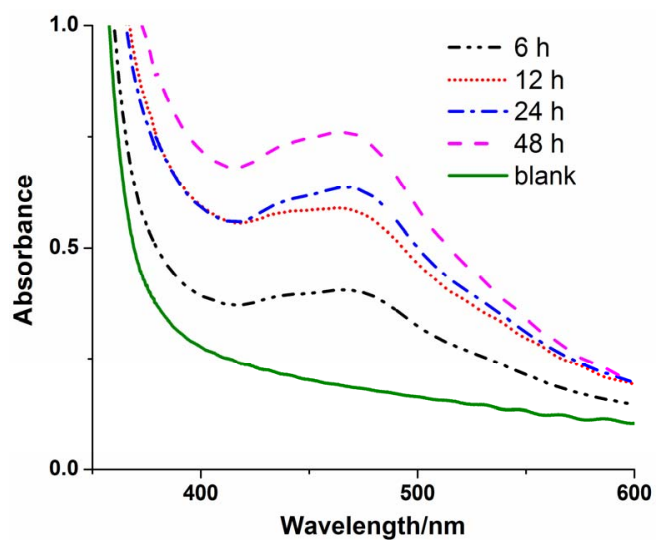

Figure 6. Dependency of the dipping time on the film deposition.

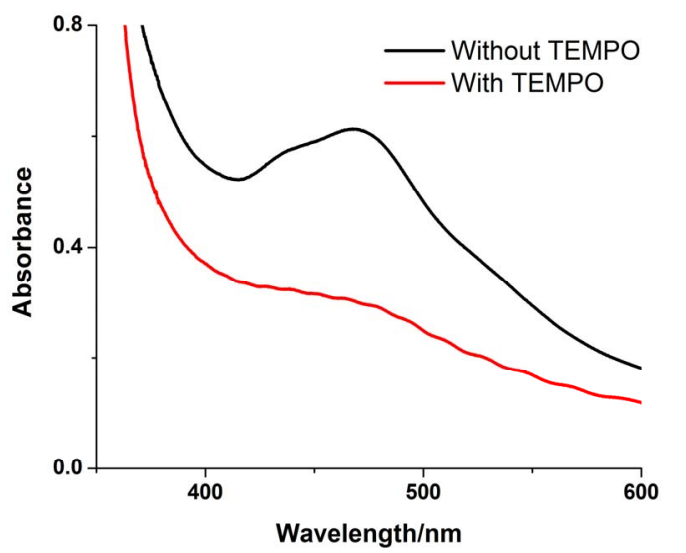

Figure 7. Effect of TEMPO on the deposition of the Ru complex.

ite film was dramatically increased to show maximum IPCE of $31.7 \%$ at $438 \mathrm{~nm}$ under the standard AM $1.5 \mathrm{G}$ irradiation conditions. The highly improved IPCE would arise from the electronic neutrality of the composite even after charge separation, which was secured by sodium 4-vinylbennzenesulfonate, that is, sodium cations would neutralize electron-accepting dyes while sulfonate groups would neutralize electron-donating dyes. Thus, the composite film could provide much higher IPCE by the inhibition of a back electron transfer.

\section{Conclusion}

A novel ruthenium complex di(isothiocyanato)bis(4methyl-4'-vinyl-2,2'-bipyridine)ruthenium(II) [(NCS $)_{2}$ (mvbpy) $\left.)_{2} \mathrm{Ru}(\mathrm{II})\right]$ having vinyl groups was synthesized by a method similar to that of (bpy $)_{2}(\mathrm{NCS})_{2} \mathrm{Ru}(\mathrm{II})$, in which 4-methyl-4'-vinyl-2,2'-bipyridine (mvbpy) was used in place of 2,2'-bipyridine (bpy). The Ru complex could be immobilized on the surface of a $\mathrm{TiO}_{2}$-coated, fluorinedoped tin oxide $\left(\mathrm{TiO}_{2} /\right.$ FTO) electrode by a newly developed, electrochemically induced film formation method, which consists of three steps: the electrolysis of an elec- 
trode, the washing of the electrode, and the film deposition of the Ru complex upon immersing the electrode in a solution of the Ru complex. This is the first example of the immobilization of a $\mathrm{Ru}$ (II) complex without a functional group reactive with $\mathrm{TiO}_{2}$, such as -COOH, $-\mathrm{PO}(\mathrm{OH})_{3},-\mathrm{OH}$, and $-\mathrm{SH}$. The $\mathrm{Ru}(\mathrm{II})$ complex film on $\mathrm{TiO}_{2} /$ FTO thus obtained gave maximum incident photonto-current efficiency (IPCE) of $1.2 \%$. In contrast, the composite film consisting of the $\mathrm{Ru}(\mathrm{II})$ complex and sodium 4-vinylbenzenesulfonate showed much higher maximum IPCE of $31.7 \%$ at $438 \mathrm{~nm}$. The new method for the generation of active sites on the surface of a $\mathrm{TiO}_{2} /$ FTO electrode by electrolysis and the new strategy for the stabilization of charge separated dyes would bring about the development of highly efficient dye-sensitized solar cells.

\section{Acknowledgements}

We acknowledge Dr. Masataka Ohtani and Dr. Yasuhiro Ishida (RIKEN, Advanced Science Institute) for the MALDI-TOF MS measurement.

\section{REFERENCES}

[1] B. O'Regan and M. Gratzel, "A Low-Cost, High-Efficiency Solar Cell Based on Dye-Sensitized Colloidal $\mathrm{TiO}_{2}$ Films," Nature, Vol. 353, No. 6346, 1991, pp. 737-740. doi:10.1038/353737a0

[2] K. C. D. Robson, B. D. Koivisto, A. Yella, B. Sporinova, M. K. Nazeeruddin, T. Baumgartner, M. Grätzel and C. P. Berlinguette, "Design and Development of Functionalized Cyclometalated Ruthenium Chromophores for Light-Harvesting Applications," Inorganic Chemistry, Vol. 50, No. 12, 2011, pp. 5494-5508. doi:10.1021/ic200011m

[3] A. Yella, H.-W. Lee, H. N. Tsao, C. Yi, A. K. Chandiran, M. K. Nazeeruddin, E. W.-G. Diau, C.-Y. Yeh, S. M. Zakeeruddin and M. Grätzel, "Porphyrin-Sensitized Solar Cells with Cobalt (II/III)-Based Redox Electrolyte Exceed 12 Percent Efficiency," Science, Vol. 334, No. 6056, 2011, pp. 629-634. doi:10.1126/science. 1209688

[4] R. Argazzi, N. Y. Murakami Iha, H. Zabri, F. Odobel and C. A. Bignozzi, "Design of Molecular Dyes for Application in Photoelectrochemical and Electrochromic Devices Based on Nanocrystalline Metal Oxide Semiconductors," Coordination Chemistry Reviews, Vol. 248, No. 13-14, 2004, pp. 1299-1316. doi:10.1016/j.ccr.2004.03.026

[5] N. Koumura, Z.-S. Wang, S. Mori, M. Miyashita, E. Suzuki and K. Hara, "Alkyl-Functionalized Organic Dyes for Efficient Molecular Photovoltaics," Journal of the American Chemical Society, Vol. 128, No. 44, 2006, pp. 14256-14257. doi:10.1021/ja0645640

[6] E. Bae and W. Choi, "Effect of the Anchoring Group (Carboxylate vs Phosphonate) in Ru-Complex-Sensitized $\mathrm{TiO}_{2}$ on Hydrogen Production under Visible Light," The Journal of Physical Chemistry B, Vol. 110, No. 30, 2006, pp. 14792-14799. doi:10.1021/jp062540+

[7] P. Liska, N. Vlachopoulos, M. K. Nazeeruddin, P. Comte,
M. Graetzel, “cis-Diaquabis(2,2'-bipyridyl-4,4'-dicarboxylate)ruthenium(II) Sensitizes Wide Band Gap Oxide Semiconductors very Efficiently over a Broad Spectral Range in the Visible," Journal of the American Chemical Society, Vol. 110, No. 11, 1988, pp. 3686-3687. doi:10.1021/ja00219a068

[8] K. Hanson, M. K. Brennaman, H. Luo, C. R. Glasson, J. J. Concepcion, W. Song and T. J. Meyer, "Photostability of Phosphonate-Derivatized, Ru(II) Polypyridyl Complexes on Metal Oxide Surfaces," ACS Applied Materials \& Interfaces, Vol. 4, No. 3, 2012, pp. 1462-1469. doi:10.1021/am201717x

[9] T. Dittrich, B. Neumann and H. Tributsch, "Sensitization via Reversibly Inducible $\mathrm{Ru}\left(\mathrm{dcbpyH}_{2}\right)_{2}(\mathrm{NCS})_{2}-\mathrm{TiO}_{2}$ Charge-Transfer Complex," The Journal of Physical Chemistry C, Vol. 111, No. 5, 2007, pp. 2265-2269. doi:10.1021/jp065830z

[10] G. Li, P. G. Bomben, K. C. D. Robson, S. I. Gorelsky, C. P. Berlinguette and M. Shatruk, "Ru Complexes of Thienyl-Functionalized Dipyrrins as NCS-Free Sensitizers for the Dye-Sensitized Solar Cell," Chemical Communications, Vol. 48, No. 70, 2012, pp. 8790-8792. doi: $10.1039 / \mathrm{c} 2 \mathrm{cc} 34311 \mathrm{~h}$

[11] P. H. Xie, Y. J. Hou, T. X. Wei, B. W. Zhang, Y. Cao and C. H. Huang, "Synthesis and Photoelectric Studies of Ru(II) Polypyridyl Sensitizers," Inorganica Chimica Acta, Vol. 308, No. 1, 2000, pp. 73-79. doi:10.1016/S0020-1693(00)00214-0

[12] M. K. Nazeeruddin, A. Kay, I. Rodicio, R. HumphryBaker, E. Mueller, P. Liska, N. Vlachopoulos and M. Graetzel, "Conversion of Light to Electricity by cis-X2bis(2,2'bipyridyl-4,4'-dicarboxylate)ruthenium(II) Charge-Transfer Sensitizers (X $=\mathrm{Cl}-, \mathrm{Br}-, \mathrm{I}-, \mathrm{CN}-$, and $\mathrm{SCN}-$ ) on Nanocrystalline Titanium Dioxide Electrodes," Journal of the American Chemical Society, Vol. 115, No. 14, 1993, pp. 6382-6390. doi:10.1021/ja00067a063

[13] K. C. D. Robson, B. D. Koivisto, A. Yella, B. Sporinova, M. K. Nazeeruddin, T. Baumgartner, M. Grätzel and C. P. Berlinguette, "Design and Development of Functionalized Cyclometalated Ruthenium Chromophores for Light-Harvesting Applications," Inorganic Chemistry, Vol. 50, No. 12, 2011, pp. 5494-5508. doi:10.1021/ic200011m

[14] M. Grätzel, "Dye-Sensitized Solar Cells," Journal of Photochemistry and Photobiology C: Photochemistry Reviews, Vol. 4, No. 2, 2003, pp. 145-153.

doi:10.1016/S1389-5567(03)00026-1

[15] Y.-J. Hou, P.-H. Xie, B.-W. Zhang, Y. Cao, X.-R. Xiao and W.-B. Wang, "Influence of the Attaching Group and Substituted Position in the Photosensitization Behavior of Ruthenium Polypyridyl Complexes," Inorganic Chemistry, Vol. 38, No. 26, 1999, pp. 6320-6322. doi:10.1021/ic990001w

[16] H.-J. Park, K. H. Kim, S. Y. Choi, H.-M. Kim, W. I. Lee, Y. K. Kang and Y. K. Chung, "Unsymmetric Ru(II) Complexes with N-Heterocyclic Carbene and/or Terpyridine Ligands: Synthesis, Characterization, Ground- and Excited-State Electronic Structures and Their Application for DSSC Sensitizers," Inorganic Chemistry, Vol. 49, No. 16, 2010, pp. 7340-7352. doi:10.1021/ic100325c 
[17] M. Furue, T. Yoshidzumi, S. Kinoshita, T. Kushida, S.-I. Nozakura and M. Kamachi, "Intramolecular Energy Transfer in Covalently Linked Polypyridine Ruthenium(II)/ Osmium(II) Binuclear Complexes. Ru(II)(bpy) ${ }_{2}$ Mebpy$\left(\mathrm{CH}_{2}\right)_{\mathrm{n}}$-MebpyOs(II)(bpy $)_{2}(\mathrm{n}=2,3,5$, and 7)," Bulletin of the Chemical Society of Japan, Vol. 64, No. 5, 1991, pp. 1632-1640. doi:10.1246/bcsj.64.1632

[18] R. H. Terbrueggen, T. W. Johann and J. K. Barton, Functionalized Rhodium Intercalators for DNA Recognition," Inorganic Chemistry, Vol. 37, No. 26, 1998, pp. 68746883. doi:10.1021/ic980837i

[19] K. Sumi, M. Furue and S.-I. Nozakura, (1985) "Efficiency of Polymer Sensitizer in Photosensitized Reaction of Tris(bipyridine)ruthenium(II) Complex-Containing Polymer," Journal of Polymer Science: Polymer Chemistry
Edition, Vol. 23, No. 12, pp. 3059-3067. doi:10.1002/pol.1985.170231214

[20] Z. Yu, H. M. Najafabadi, Y. Xu, K. Nonomura, L. Sun and L. Kloo, "Ruthenium Sensitizer with a Thienylvinylbipyridyl Ligand for Dye-Sensitized Solar Cells," Dalton Transactions, Vol. 40, No. 33, 2011, pp. 8361-8366. doi:10.1039/c1dt10210a

[21] V. Aranyos, J. Hjelm, A. Hagfeldt and H. Grennberg, "Electropolymerisable Bipyridine Ruthenium(II) Complexes. Synthesis and Electrochemical Characterisation of 4-(3-methoxystyryl)- and 4,4[prime or minute]-di(3-methoxystyryl)-2,2[prime or minute]-bipyridine Ruthenium Complexes," Journal of the Chemical Society, Dalton Transactions, No. 8, 2001, pp. 1319-1325. doi:10.1039/b008697p 